\title{
Pilot-scale anaerobic/anoxic/oxic/oxic biofilm process treating coking wastewater
}

\author{
Xin Zhou, ${ }^{a, b}$ Yaxin Li, ${ }^{b *}$ Yi Zhao $^{b}$ and Xiuping Yue ${ }^{b}$
}

\begin{abstract}
BACKGROUND: Biological treatment efficiency of coking wastewater is rather poor, especially for chemical oxygen demand (COD) and ammonia-nitrogen $\left(\mathrm{NH}_{4}^{+}-\mathrm{N}\right)$ removal due to its complex composition and high toxicity.

RESULTS: A pilot-scale anaerobic/anoxic/oxic/oxic $\left(A^{2} / O^{2}\right)$ biofilm system has been developed to treat coking wastewater, focusing attention on the $\mathrm{COD}$ and $\mathrm{NH}_{4}^{+}-\mathrm{N}$ removal efficiencies. Operational results over 239 days showed that hydraulic retention time (HRT) of the system had a great impact on simultaneous removals of COD and $\mathrm{NH}_{4}^{+}-\mathrm{N}$. At $\mathrm{HRT}$ of $116 \mathrm{~h}$, total removal efficiencies of $\mathrm{COD}$ and $\mathrm{NH}_{4}^{+}-\mathrm{N}$ were $92.3 \%$ and $97.8 \%$, respectively, reaching the First Grade discharge standard for coking wastewater in China. Adequate HRT, anoxic removal of refractory organics and two-step aerobic bioreactors were considered to be effective measures to obtain satisfactory coking effluent quality using the $A^{2} / O^{2}$ biofilm system. The correlation between removal characteristics of pollutants and spatial distributions of biomass along the height of upflow bioreactors was also revealed.
\end{abstract}

CONCLUSION: The study suggests that it is feasible to apply the $A^{2} / O^{2}$ biofilm process for coking wastewater treatment, achieving desirable effluent quality and steady process performance.

(c) 2012 Society of Chemical Industry

Keywords: anaerobic/anoxic/oxic/oxic $\left(\mathrm{A}^{2} / \mathrm{O}^{2}\right)$; biofilm bioreactor; coking wastewater; removal efficiency; hydraulic retention time(HRT)

\section{INTRODUCTION}

As one of the largest coke producing countries in the world, China has currently approximately $45 \%$ of worldwide total production. Over one-third of national coke production was supplied from Shanxi Province in North China. According to statistics, 51.87 million tons of coking wastewater are discharged annually, accounting for $30 \%$ of the overall emissions of industrial wastewater in the whole province. ${ }^{1}$ This figure will rise further in the coming years with the development of the coal and coking industry in Shanxi.

Coking wastewater, generated from coal conversion processes such as coal coking, coal gas purification and liquefaction, and the refining of coal by-products in coke plants, ${ }^{2-4}$ is a complex industrial wastewater characterized by a large amount of organic matters, suspended solids, ammonia and other toxic compounds such as phenols and cyanide, ,,6 leading to harmful effects on water environment and human health without properly treatment. Therefore, pollution control of coking wastewater has become an important topic for industrial wastewater treatment.

Biological treatment has been widely used as an efficient and cost-effective method for coking wastewater treatment until now, while physico-chemical methods generally are considered as options for pre- ${ }^{5,7}$ or post-treatment of wastewater. ${ }^{8-11}$ Since the 1970 s and 1980s, a wide range of biological treatment reactors and processes have been developed and researched in North America, China, South Korea, Australia, and Spain. These processes included conventional activated sludge (CAS), $3,6,12$ fixed biofilm system, ${ }^{13-15}$ hybrid system, ${ }^{16}$ oxic/anoxic (O/A) process, ${ }^{17,18}$ anoxic/oxic process $(\mathrm{A} / \mathrm{O}),{ }^{19,20}$ anaerobic/anoxic/oxic
$\left(\mathrm{A}^{2} / \mathrm{O}\right)$ process, ${ }^{21-23}$ anoxic/oxic/oxic $\left(\mathrm{A} / \mathrm{O}^{2}\right)$ process, ${ }^{24-26}$ sequencing batch reactor (SBR), ${ }^{5,27}$ biological fluidized-bed reactor $(\mathrm{FBR})^{28-30}$ and membrane bioreactor (MBR). ${ }^{31,32}$

Unfortunately, the biologically treated effluents from these processes do not meet the stringent effluent standard in China for $\mathrm{COD} \leq 100 \mathrm{mg} \mathrm{L}^{-1}$ and $\mathrm{NH}_{4}^{+}-\mathrm{N} \leq 15 \mathrm{mg} \mathrm{L}^{-1}$, although phenols and cyanide in the effluents are lower than regulation limits. For $\mathrm{NH}_{4}^{+}-\mathrm{N}$ removal, the activity of autotrophic nitrifying bacteria was depressed by high concentrations of organics and ammonia as well as other highly toxic or inhibitory compounds, ${ }^{33}$ leading to poor nitrification in a single oxic bioreactor; in addition, it is difficult to retain sufficient nitrifying bacteria in the system, especially in the CAS process, ${ }^{23}$ due to their slow reproduction at low biomass concentration and shorter sludge age. In terms of chemical oxygen demand (COD) removal, a great variety of refractory compounds in the coking wastewater involving mono- and polycyclic aromatics hydrocarbons (PAHs) and heterocyclic aromatic hydrocarbons containing nitrogen, oxygen and sulfur ${ }^{7,23,34}$ are difficult to biodegrade causing COD

\footnotetext{
* Correspondence to: Yaxin Li, College of Environmental Science and Engineering, Taiyuan University of Technology, Taiyuan 030024, P.R. China. E-mail:yxl@tyut.edu.cn

a Research Center for Eco-Environmental Sciences, Chinese Academy of Sciences, Beijing, 100085, P.R. China

b College of Environmental Science and Engineering, Taiyuan University of Technology, Taiyuan, 030024, P.R. China
} 
concentrations higher than $200-250 \mathrm{mg} \mathrm{L}^{-1}$ in the final effluent even though a very long hydraulic retention time (HRT) is maintained in the single-aerobic system. ${ }^{6}$ The high toxicity and complicated composition of coking wastewater seem to be the main factors preventing meeting the discharge standards for both $\mathrm{COD}$ and $\mathrm{NH}_{4}^{+}-\mathrm{N}$ in coking effluent.

Compared with other activated sludge processes, attached growth systems with fixed biofilm maintain a very long sludge retention time and higher biomass to achieve process efficiency and stability without poor sludge settle-ability problems in the presence of highly toxic compounds. The aerobic process with anaerobic and anoxic treatment units enhanced the degradation of refractory carbonaceous organics, and autotrophic nitrifying bacteria were easily developed within two-step aerobic reactors: COD was removed in the first aerobic reactor and $\mathrm{NH}_{4}^{+}-\mathrm{N}$ was removed in the second aerobic reactor under the lower organic loading and toxicity. Accordingly, the objective of this present study is to characterize the performance of a novel four-stage anaerobic/anoxic/oxic/oxic $\left(\mathrm{A}^{2} / \mathrm{O}^{2}\right)$ combined biofilm process $^{35}$ for simultaneous removal of carbon and nitrogen from coking wastewater at varying HRTs. Removal characteristics of $\mathrm{COD}, \mathrm{NH}_{4}^{+}-\mathrm{N}$ and $\mathrm{NO}_{3}^{-}-\mathrm{N}$ as well as spatial distribution in microbial biomass within the upflow biofilm reactors are also reported.

\section{MATERIALS AND METHODS}

\section{Experimental setup}

The experiment was carried out in a pilot-scale combined system, consisting of four up-flow fixed biofilm bioreactors: anaerobic $\left(A_{1}\right)$-anoxic $\left(A_{2}\right)$-oxic $\left(O_{1}\right)$ and oxic $\left(O_{2}\right)$ (in Fig. 1$)$ located at a coking plant of Tongshida Co. Ltd in Linfen, Shanxi Province. The working volumes of the four reactors were, respectively, 3 , $4.8,4.8$ and $4.8 \mathrm{~m}^{3}$. Reactors $\mathrm{A}_{1}, \mathrm{~A}_{2}$ and $\mathrm{O}_{2}$ were packed with ceramsite and Reactor $\mathrm{O}_{1}$ was packed with polypropylene media. Characteristic parameters of carriers are listed in Table 1. Sampling ports were installed at different heights of the packing layer in Reactors $A_{1}, A_{2}$ and $O_{2}$. Bio-contact oxidation reactor $\left(O_{1}\right)$ and biological aerated filter (BAF) $\left(\mathrm{O}_{2}\right)$ were supplied with air by the compressor. Backwashing of the filter at regular intervals was also required to avoid clogging of the carriers.
Table 1. Characteristic parameters of carriers

\begin{tabular}{lcc|} 
Specification & $\begin{array}{c}\text { Hollow plastic } \\
\text { balls }\end{array}$ & $\begin{array}{c}\text { Ceramic } \\
\text { particles }\end{array}$ \\
\hline Type & Ball & Granular \\
Specific surface area $\left(\mathrm{m}^{2} \mathrm{~m}^{-3}\right)$ & 236 & 3900 \\
Porosity (\%) & $90 \%$ & $\geq 55 \%$ \\
Hydrochloric acid soluble rate (\%) & $\leq 0.22$ & $\leq 0.22$ \\
Sodium hydroxide soluble rate (\%) & $\leq 15.0$ & $\leq 15.0$ \\
Diameter $(\mathrm{mm})$ & 50 & $3-7$ \\
\end{tabular}

Table 2. Characteristics of influent coking wastewater

\begin{tabular}{lcccc|} 
Parameter & Unit & $\begin{array}{c}\text { Average } \\
\text { value }\end{array}$ & $\begin{array}{c}\text { SD, standard } \\
\text { deviation }\end{array}$ & $\begin{array}{c}\text { Number of } \\
\text { samples }\end{array}$ \\
\hline $\mathrm{pH}$ & - & 8.3 & 0.3 & 32 \\
$\mathrm{BOD}_{5}$ & $\mathrm{mg} \mathrm{L}^{-1}$ & 303 & 61 & 24 \\
$\mathrm{COD}$ & $\mathrm{mg} \mathrm{L}^{-1}$ & 1195 & 297 & 30 \\
$\mathrm{NH}_{4}^{+}-\mathrm{N}$ & $\mathrm{mg} \mathrm{L}^{-1}$ & 228.2 & 55.5 & 32 \\
$\mathrm{Phenol}_{\text {Cyanide }}$ & $\mathrm{mg} \mathrm{L}^{-1}$ & 255 & 117 & 5 \\
& $\mathrm{mg} \mathrm{L}^{-1}$ & 8 & 2 & 5 \\
\hline
\end{tabular}

\section{Wastewater and seed sludge}

The seed sludge for anaerobic/anoxic reactors and aerobic reactors of the $A^{2} / \mathrm{O}^{2}$ system was, respectively, obtained from the anoxic tank and aerobic aeration tank of a coke-plant wastewater treatment facility of Tongshida Co. Ltd. During the experiment, raw coking wastewater was collected from the wastewater tank. The influent coking wastewater in this study (Table 2) was rather complex and poorly degraded $\left(\mathrm{BOD}_{5} / \mathrm{COD}\right.$ ratio: $\left.0.16-0.25\right)$ with a low carbon source (COD/NH${ }_{4}^{+}-\mathrm{N}$ ratio: $\left.3-5\right) . \mathrm{K}_{2} \mathrm{HPO}_{4}$ was added into the influent tank to provide sufficient nutrients for normal growth of the microorganisms. $\mathrm{pH}$ and alkalinity were controlled through the addition of $\mathrm{NaHCO}_{3}$ solution into the second aerobic reactor to compensate the loss of alkalinity due to nitrification. The final effluent $\mathrm{pH}$ was maintained above 7.0 and the alkalinity was not less than $80 \mathrm{mg} \mathrm{L}^{-1}$ (as $\mathrm{CaCO}_{3}$ ).

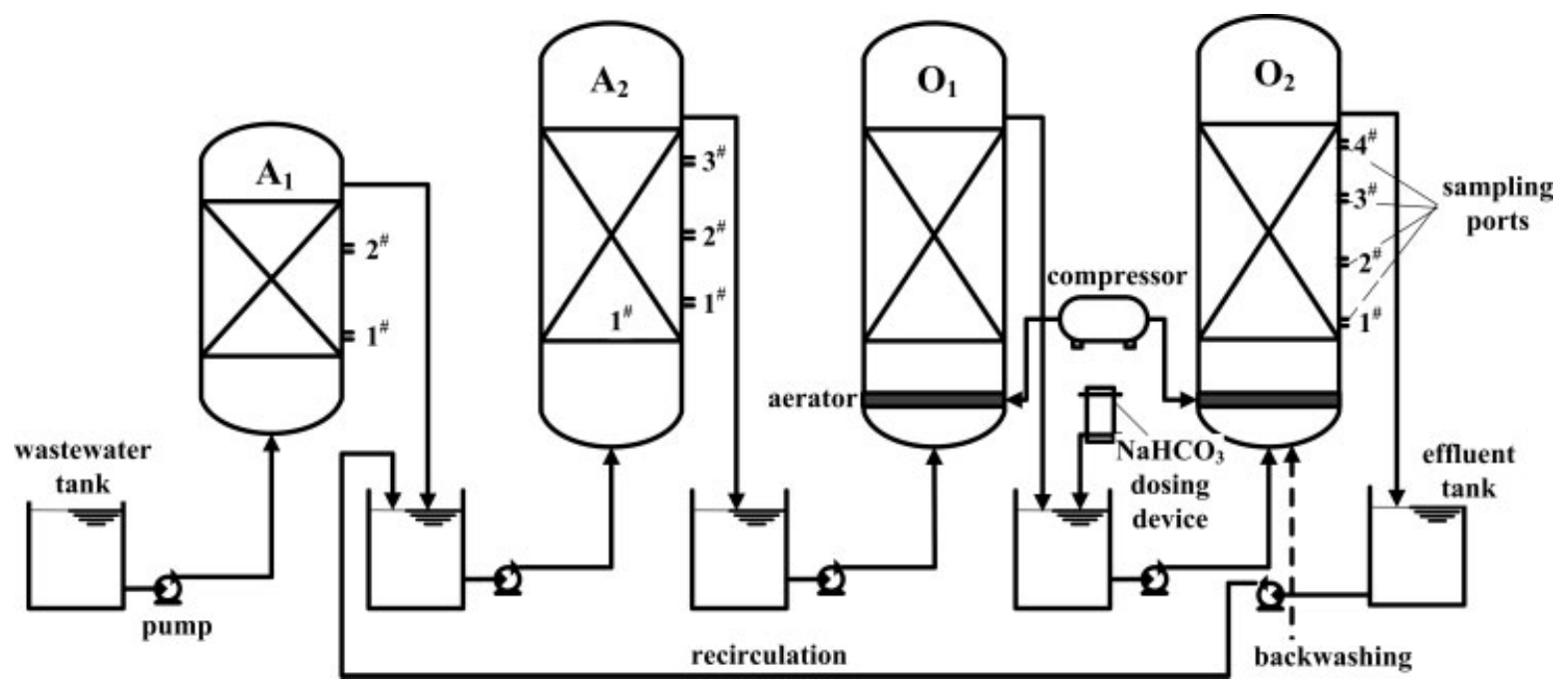

Figure 1. Schematic diagram of pilot-scale $\mathrm{A}^{2} / \mathrm{O}^{2}$ biofilm system. 


\begin{tabular}{lcccccc|}
\hline Table 3. & \multicolumn{6}{c|}{ Operating conditions for experimental periods } \\
Period & $\begin{array}{c}\mathrm{HRT}_{\text {Total }} \\
(h)\end{array}$ & $\begin{array}{c}\mathrm{HRT}_{\mathrm{A} 1} \\
(h)\end{array}$ & $\begin{array}{c}\mathrm{HRT}_{\mathrm{A} 2} \\
(h)\end{array}$ & $\begin{array}{c}\mathrm{HRT}_{\mathrm{O} 1} \\
(h)\end{array}$ & $\begin{array}{c}\mathrm{HRT}_{\mathrm{O} 2} \\
(h)\end{array}$ & Days \\
\hline $\mathrm{R}_{1}$ & 43.5 & 7.5 & 12 & 12 & 12 & $0-63$ \\
$\mathrm{R}_{2}$ & 87 & 15 & 24 & 24 & 24 & $64-120$ \\
$\mathrm{R}_{3}$ & 116 & 20 & 32 & 32 & 32 & $121-190$ \\
$\mathrm{R}_{4}$ & 174 & 30 & 48 & 48 & 48 & $191-238$ \\
\hline
\end{tabular}

\section{Operating conditions}

During the pilot experiment, which lasted for 239 days, four different long-term steady-state experimental runs $\left(R_{1}-R_{4}\right)$ were carried out after 40-day system start-up period. Operating conditions for experimental periods are listed in Table 3 . Throughout the whole experimental period, influent wastewater temperature was in the range $25-35^{\circ} \mathrm{C}$, DO concentrations in the aerobic reactors were kept between 4 and $5 \mathrm{mg} \mathrm{L}^{-1}$ and nitrifying recirculation ratio from Reactor $\mathrm{O}_{2}$ to Reactor $\mathrm{A}_{2}$ was controlled at 3, which was the optimum for denitrification of the $A^{2} / O^{2}$ system, based on previous studies.

\section{Analytical methods}

Temperature, $\mathrm{pH}$, dissolved oxygen (DO) and alkalinity were measured daily. $\mathrm{COD}, \mathrm{NH}_{4}^{+}-\mathrm{N}, \mathrm{NO}_{3}^{-}-\mathrm{N}$ were analyzed weekly. $\mathrm{COD}, \mathrm{NH}_{4}^{+}-\mathrm{N}, \mathrm{NO}_{3}^{-}-\mathrm{N}$ and alkalinity in the influent and effluent of each single bioreactor were analyzed according to standard methods. ${ }^{36}$ Temperature and $\mathrm{pH}$ were measured with a $\mathrm{pH}$ meter (WTW Multi340i). DO was measured using a portable DO meter (YSI-500). The biofilm biomass of each bioreactor was analyzed as detailed by Zhang and Li. ${ }^{37}$ Specified amounts of packing media from sampling ports within reactors were immediately soaked with $20 \%$ ammonia water and boiled for $15 \mathrm{~min}$, the retained liquid was poured out and the procedure repeated. The packing media were also flushed with distilled water. The liquid and leacheate were collected into a large vessel and mixed together. A small volume was taken from the vessel to measure MLSS/MLVSS according to standard methods, ${ }^{36}$ representing biomass concentrations of biofilm attached to the packing media. The average biomass of each bioreactor was calculated from

$$
M L(V) S S=\frac{\sum M_{1 i} \cdot h_{1}+\sum M_{2 i} \cdot h_{2}+\ldots+\sum M_{n i} \cdot h_{i}}{h_{1}+h_{2}+\ldots+h_{i}}
$$

where $M L(V) S S$ is mixed liquor (volatile)suspended solids, $M_{n i}$ is the biomass at the specified height of the packing layer in the bioreactor, and $h_{i}$ is the full height of the packing layer in the bioreactor.

\section{RESULTS AND DISCUSSION \\ Overall performance of $\mathrm{A}^{2} / \mathrm{O}^{2}$ system}

Figure 2 shows the profile of COD concentration in the influent and effluent and the removal efficiency of the $\mathrm{A}^{2} / \mathrm{O}^{2}$ system during the experimental periods. As shown in Fig. 2, the COD concentration in the final effluent from the system was maintained below $300 \mathrm{mg} \mathrm{L}^{-1}$, although the COD at the influent varied between 758 and $1873 \mathrm{mg} \mathrm{L}^{-1}$. This indicated the ability of the multistage biofilm system to withstand organic loading shocks. As the HRT was increased from $43.5 \mathrm{~h}$ to $116 \mathrm{~h}$, average COD removal

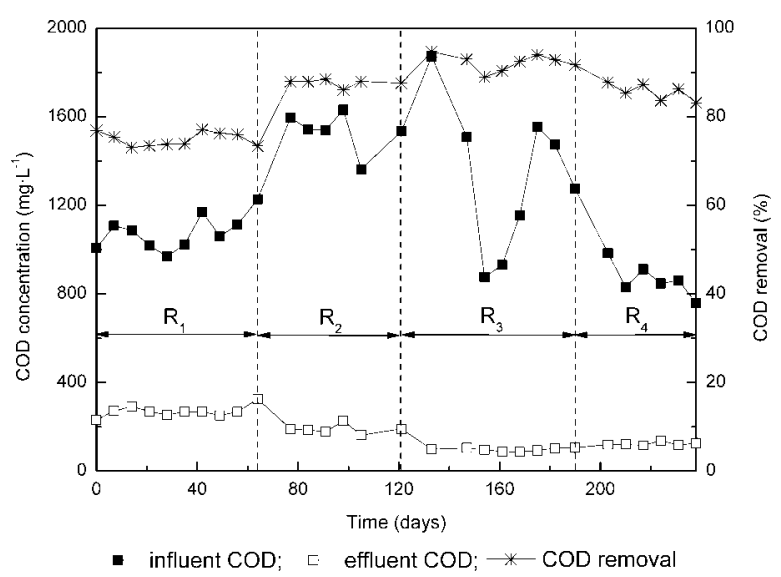

Figure 2. Influent and effluent COD concentrations and COD removal during operational periods.

efficiency was improved from $75 \%$ to $92 \%$, and the corresponding lowest effluent COD value was $98 \mathrm{mg} \mathrm{L}^{-1}$ for $\mathrm{R}_{3}$, which met the requirements of the first level of the coking wastewater discharge standards (GB8978-1996). However, it was also observed that COD removal dropped slightly when HRT was further lengthened to $174 \mathrm{~h}$ from $116 \mathrm{~h}$. One possible reason was that a too low hydraulic load rate (HLR) resulting from extremely long HRT could aggravate the clogging of carriers without sufficient washing out of biofilm, weakening the renewal of the biofilm growth. Furthermore, lower influent organic loading rate (OLR) also led to a reduction in COD removal capacity. In general, it was concluded that proper selection of HRT played an important role in COD removal efficiency. Longer system retention times helped to eliminate more refractory organic compounds from the coking wastewater.

Figure 3 illustrates the profile of $\mathrm{NH}_{4}^{+}-\mathrm{N}$ concentration in the influent and effluent and removal efficiency of the $\mathrm{A}^{2} / \mathrm{O}^{2}$ system during the experimental periods. Effluent $\mathrm{NO}_{3}^{-}-\mathrm{N}$ is also given in the same figure demonstrating the nitrification performance. As shown in Fig. 3, the impact of HRT on ammonia removal was much more evident than on organics removal. Generally, $\mathrm{NH}_{4}^{+}-\mathrm{N}$ removal efficiency increased with increased HRT. There was no obvious removal of $\mathrm{NH}_{4}^{+}-\mathrm{N}$ at a short HRT of $43.5 \mathrm{~h}$ at $\mathrm{R}_{1}$, while $\mathrm{NH}_{4}^{+}-\mathrm{N}$ concentration in the effluent was sharply decreased with sufficiently long $\mathrm{HRT}$. $\mathrm{NH}_{4}^{+}-\mathrm{N}$ removal efficiency reached $89-99 \%$ when HRT was extended to more than $87 \mathrm{~h}$. As $\mathrm{NH}_{4}^{+}-\mathrm{N}$ was converted to $\mathrm{NO}_{3}^{-}-\mathrm{N}$ via nitrification under aerobic conditions, effluent $\mathrm{NO}_{3}^{-}-\mathrm{N}$ concentration was directly correlated with the degree of $\mathrm{NH}_{4}^{+}-\mathrm{N}$ removal. It was clear that little $\mathrm{NO}_{3}^{-}-\mathrm{N}$ was produced in the effluent due to no nitrification at $\mathrm{R}_{1}$, while levels as high as $95 \mathrm{mg} \mathrm{L}^{-1} \mathrm{NO}_{3}^{-}-\mathrm{N}$ at $\mathrm{R}_{4}$ indicated complete nitrification. Nitrification was performed by nitrifying bacteria whose growth rate was slower than heterotrophic bacteria. Therefore, the longer HRT favored reproduction and heightened activity of nitrifying bacteria due to sufficient degradation of organic matter and nitrification inhibitory compounds.

Figures 2 and 3 show that it was necessary to maintain longer total system HRT to achieve better process efficiency during steady operation. In our study, the optimal HRT was $116 \mathrm{~h}$ for simultaneous carbon and nitrogen removals from the coking wastewater.

\section{Removal efficiency in each bioreactor of $A^{2} / 0^{2}$ system}

To clearly identify the performance within each unit of the $\mathrm{A}^{2} / \mathrm{O}^{2}$ system, $\mathrm{COD}$ and $\mathrm{NH}_{4}^{+}-\mathrm{N}$ removal efficiencies of each 


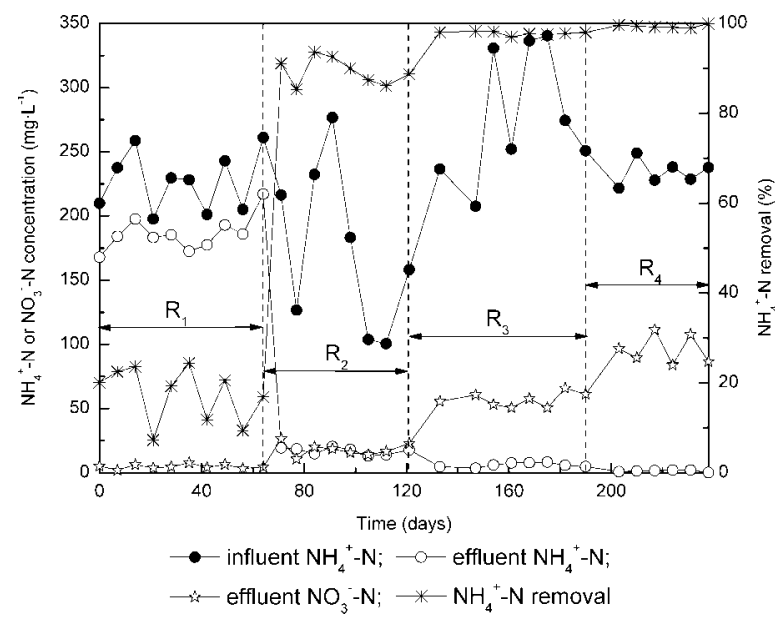

Figure 3. Influent $\mathrm{NH}_{4}^{+}-\mathrm{N}$ and effluent $\mathrm{NH}_{4}^{+}-\mathrm{N}, \mathrm{NO}_{3}^{-}-\mathrm{N}$ concentrations and $\mathrm{NH}_{4}^{+}-\mathrm{N}$ removal during operational periods.

bioreactor during different operating periods are presented in Figs 4 and 5. As shown in Fig. 4, COD was removed to varying degrees by each single bioreactor at the various HRTs. In Reactor $A_{1}, C O D$ removal varied between 5.4 and $11.6 \%$ for different HRTs due to transformation of the macromolecular structure rather than degradation of the refractory organics through hydrolysisacidification of the anaerobic pretreatment, leading to improved biodegradability of wastewater. ${ }^{7,14}$ Obviously, most organics were removed by subsequent treatment units. More than $50 \%$ COD removal occurred in Reactor $A_{2}$ for both $R_{3}$ and $R_{4}$, while anoxic removal of COD was lower than oxic removal, accounting for $81.2 \%$ and $69.2 \%$ of the overall COD removal for $R_{1}$ and $R_{2}$, respectively. The differences in distribution of COD removal depended mainly on the process efficiency of Reactor $A_{2}$. During the first two runs, COD was poorly utilized as carbon source for denitrification in the absence of sufficient electron acceptors $\left(\mathrm{NO}_{3}^{-}-\mathrm{N}\right)$ because of limited nitrification; consequently, COD was reduced only through aerobic reactions. In contrast, COD was removed in the anoxic bioreactor through denitrification when the nitrification capacity of the system was fully developed during the last two periods. The result demonstrated that the final effluent COD could meet the first grade discharge standard (below $100 \mathrm{mg} \mathrm{L}^{-1}$ in Fig. 2) when $55-60 \%$ of overall COD removal in the system was contributed by the anoxic bioreactor. Previous studies ${ }^{38-40}$ also found that large amounts of refractory or inhibitory compounds, which were non-biodegradable or slowly degradable under aerobic or anaerobic conditions, were effectively utilized as carbon sources under $\mathrm{NO}_{\mathrm{x}}^{-}-\mathrm{N}$-reducing conditions, resulting in lower effluent COD concentration than other biological processes but without recycling of nitrified effluent. ${ }^{3,6,12}$ As for a two-step aerobic process, COD removal in Reactor $\mathrm{O}_{1}$ was always higher than Reactor $\mathrm{O}_{2}$ at various loadings owing to the higher organic volumetric loading rate in the first aerobic reactor. Extremely low levels of SS in the effluent through media filtration in Reactor $\mathrm{O}_{2}$ (BAF) also encouraged lower COD values.

Unlike the profile of $\mathrm{COD}$ removal, $\mathrm{NH}_{4}^{+}-\mathrm{N}$ was almost totally removed in the aerobic bioreactors. In the anaerobic and anoxic reactor, ammonification of nitrogenous compounds gave rise to an increase in $\mathrm{NH}_{4}^{+}-\mathrm{N}$. It was observed that $\mathrm{NH}_{4}^{+}-\mathrm{N}$ removal contributed by Reactor $\mathrm{O}_{1}$ was always lower than that by Reactor $\mathrm{O}_{2}$ for each period. It is most likely that nitrifiers grow more slowly than heterotrophic bacteria in Reactor $\mathrm{O}_{1}$ due to the high OLR and

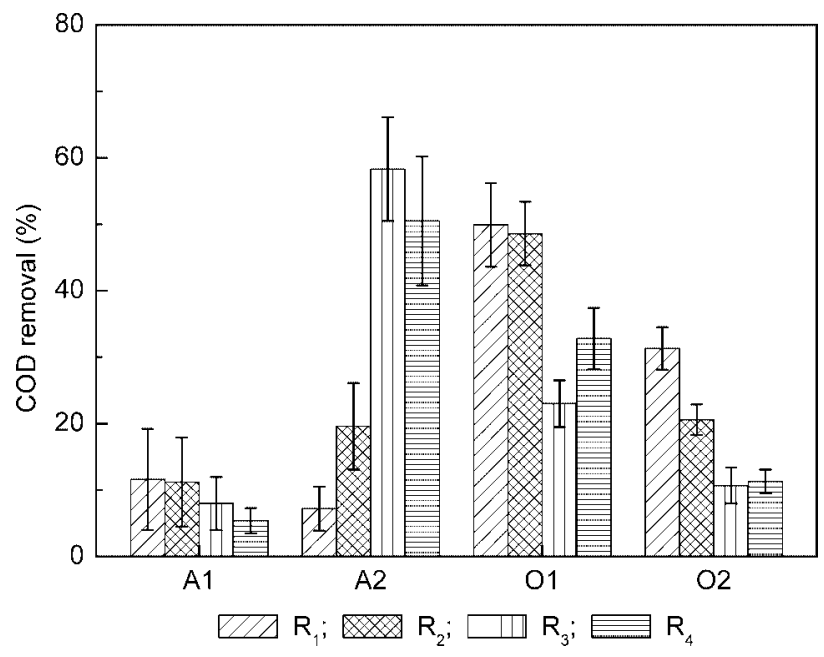

Figure 4. COD removal for each bioreactor in the total removal of the system during operational periods.

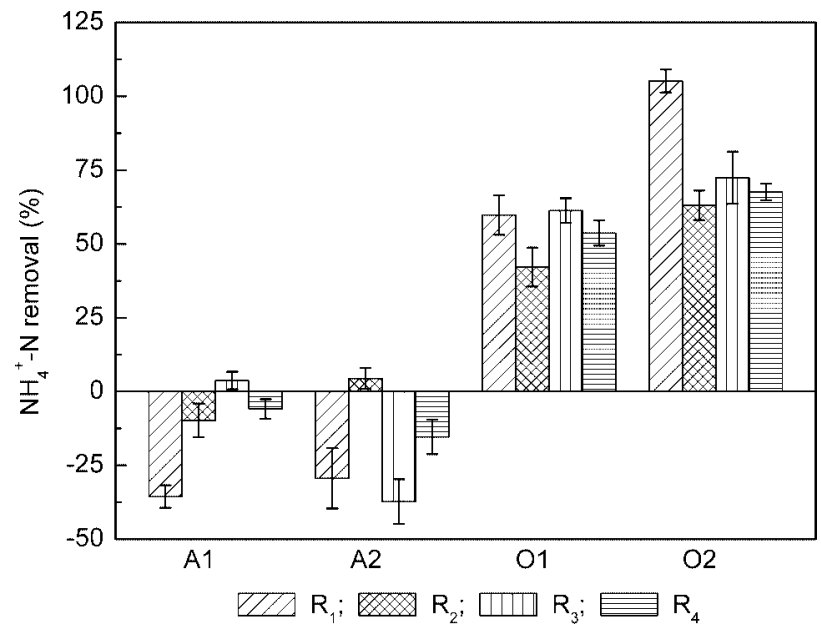

Figure 5. $\mathrm{NH}_{4}^{+}-\mathrm{N}$ removal for each bioreactor in the total removal of the system during operational periods.

toxic and inhibitory substances, while nitrifying bacteria became dominant in Reactor $\mathrm{O}_{2}$ at the low level of organic compounds and toxicity. Hence, on the basis of $\mathrm{NH}_{4}^{+}-\mathrm{N}$ removal efficiency, a two-step aerobic process with a single separate nitrifying reactor might retain more nitrifying bacteria and perform more favorable nitrification than a single aerobic system.

\section{Profile of pollutant concentration in biofilm reactors}

Figure $6(\mathrm{a})$ and $6(\mathrm{~b})$ show profiles of $\mathrm{COD}, \mathrm{NH}_{4}^{+}-\mathrm{N}$ and $\mathrm{NO}_{3}^{-}-\mathrm{N}$ along the height of Reactors $\mathrm{A}_{2}$ and $\mathrm{O}_{2}$, respectively, at an HRT of $116 \mathrm{~h}$. In Fig.6(a), it is evident that sudden drops in both $\mathrm{COD}$ and $\mathrm{NO}_{3}^{-}-\mathrm{N}$ occurred at $0.2 \mathrm{~m}$ height of the packing layer due to denitrification quickly performed at the bottom of the anoxic reactor in the presence of abundant $\mathrm{NO}_{\mathrm{x}}-\mathrm{N}$ and organic substrates, while their concentrations were changed slightly above $1 \mathrm{~m}$ height. About $25 \mathrm{mg} \mathrm{L}^{-1} \mathrm{NO}_{3}^{-}-\mathrm{N}$ were depleted through full denitrification. Instead, $\mathrm{NH}_{4}^{+}-\mathrm{N}$ concentration increased with the height of the packing layer due to transformation of organic nitrogen and cyanide compounds $\left(\mathrm{CN}^{-}\right)$under the anaerobic conditions. $^{40}$ 

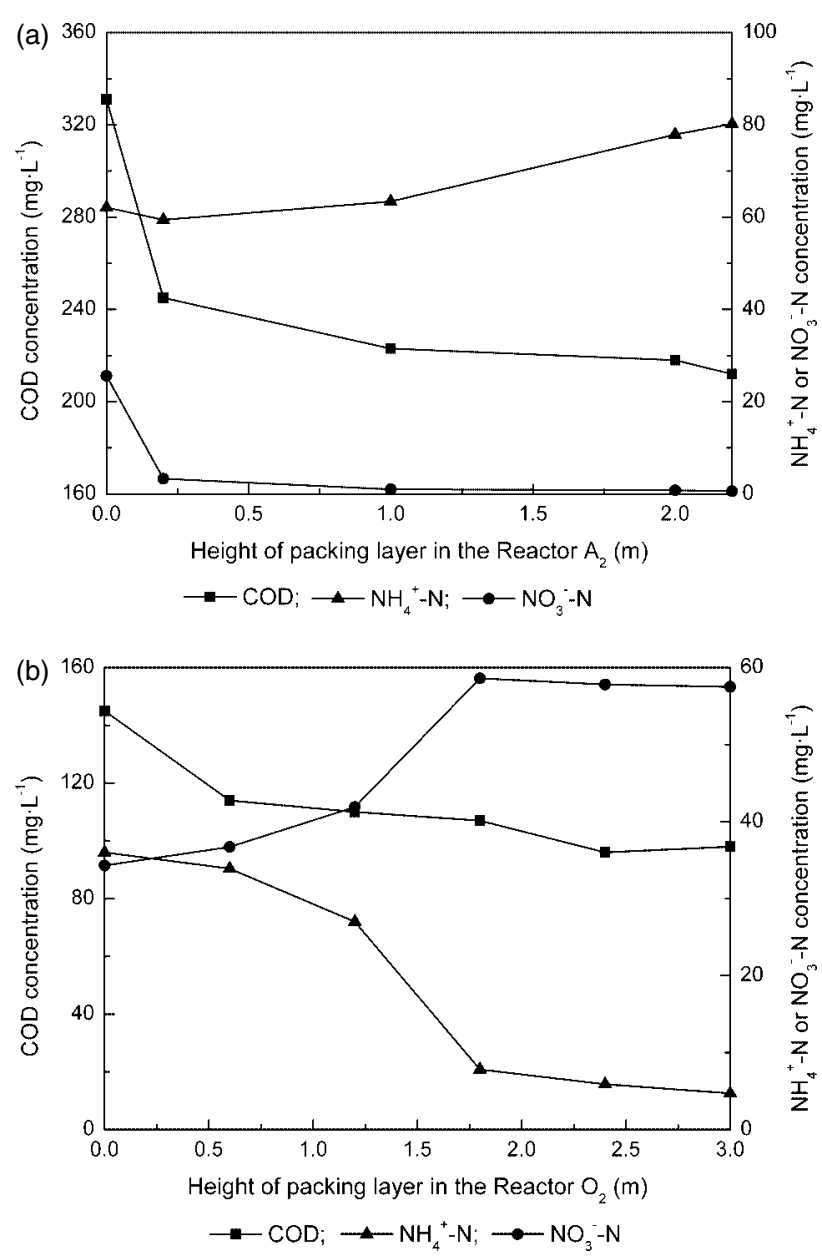

Figure 6. Profile of $\mathrm{COD}, \mathrm{NH}_{4}^{+}-\mathrm{N}$ and $\mathrm{NO}_{3}^{-}-\mathrm{N}$ along the height of carrier layer in (a) Reactor $\mathrm{A}_{2}$, (b) Reactor $\mathrm{O}_{2}$.

In Fig. 6(b), similarly to Reactor $A_{2}, C O D$ was removed chiefly in the lower part of the packing layer at $0.6 \mathrm{~m}$ of Reactor $\mathrm{O}_{2}$ where its concentration dropped from $145 \mathrm{mg} \mathrm{L}^{-1}$ to $114 \mathrm{mg} \mathrm{L}^{-1}$, while a large decrease of $\mathrm{NH}_{4}^{+}-\mathrm{N}$ concentration took place in the upper part of the reactor, implying competition between heterotrophic and nitrifying bacteria. At the bottom of the packing layer, heterotrophic bacteria were probably more active than nitrifying bacteria due to the high organic concentration. COD gradually decreased at increasing height and meanwhile, $\mathrm{NH}_{4}^{+}-\mathrm{N}$ concentration decreased rapidly from $27 \mathrm{mg} \mathrm{L}^{-1}$ to $7.8 \mathrm{mg} \mathrm{L}^{-1}$ at a height of $1.2 \mathrm{~m}$, indicating that nitrifying bacteria became dominant at the low content of organics, causing continuous accumulation of $\mathrm{NO}_{3}^{-}-\mathrm{N}$.

\section{Microbial biomass of $A^{2} / O^{2}$ system}

Biomass concentrations in each biofilm reactor at the different heights of the $A^{2} / O^{2}$ system for Day 144 during the $R_{3}$ period are summarized in Table 4. Average biomass calculated using Equation (1) for fixed biofilm reactors $A_{1}, A_{2}, O_{1}$ and $O_{2}$ were $9.2 \mathrm{~g} \mathrm{~L}^{-1}, 8.5 \mathrm{~g} \mathrm{~L}^{-1}, 11.4 \mathrm{~g} \mathrm{~L}^{-1}$ and $8.1 \mathrm{~g} \mathrm{~L}^{-1}$, respectively. High biomass concentrations within biofilm reactors could be 4 to 6 times greater than conventional activated sludge systems (2-2.5 gMLSS $\left.\mathrm{L}^{-1}\right)$, indicating high treatment efficiency of high-strength wastewater. It was observed that the amount of biomass gradually decreased from the bottom to the top
Table 4. Biofilm biomass at the different heights of reactors in the $\mathrm{A}^{2} / \mathrm{O}^{2}$ system

\begin{tabular}{|c|c|c|c|c|c|c|c|c|c|c|}
\hline & \multicolumn{2}{|c|}{$\begin{array}{c}\text { Reactor } \\
\mathrm{A}_{1}\end{array}$} & \multicolumn{3}{|c|}{$\begin{array}{c}\text { Reactor } \\
\mathrm{A}_{2}\end{array}$} & \multirow{2}{*}{$\begin{array}{c}\text { Reactor } \\
\mathrm{O}_{1}\end{array}$} & \multicolumn{4}{|c|}{ Reactor $\mathrm{O}_{2}$} \\
\hline & $1^{\mathrm{a}}$ & $2^{\mathrm{a}}$ & $1^{\mathrm{a}}$ & $2^{\mathrm{a}}$ & $3^{a}$ & & $1^{\mathrm{a}}$ & $2^{\mathrm{a}}$ & $3^{\mathrm{a}}$ & $4^{\mathrm{a}}$ \\
\hline $\operatorname{MLSS}\left(\mathrm{g} \mathrm{L}^{-1}\right)$ & 10.6 & 8.7 & 9.9 & 8.6 & 8.4 & 11.4 & 15.8 & 9 & 7.9 & 6 \\
\hline $\operatorname{MLVSS}\left(\mathrm{g} \mathrm{L}^{-1}\right)$ & 8.7 & 6.2 & 6.7 & 6.2 & 5.7 & 9.2 & 9 & 5 & 3.2 & 2.5 \\
\hline
\end{tabular}

a Representing sampling ports at different heights in Figure 1.

of the packing layer depending on the removal characteristics of the particular pollutants concentration (Fig. 6(a) and 6(b)) in the up-flow biofilm reactors. Unlike suspended growth reactors, an obvious vertical distribution pattern of microbial biomass caused by the plug-flow characteristic in the upflow attached growth bioreactors ${ }^{41}$ developed along the height of the packing layer due to the competition between the different microbial groups for space, oxygen and organic carbon. ${ }^{41}$ Thus, the multi-stage biofilm reactors were able to create a favorable growing microenvironment for the different microbial groups (heterotrophic bacteria, ammonia oxidizers and nitrite oxidizers) responsible for process performance and stability. As the total biomass could not entirely represent the quantity of these functional bacteria and the activity of microorganisms, further work will be required.

\section{CONCLUSIONS}

A pilot-scale $\mathrm{A}^{2} / \mathrm{O}^{2}$ biofilm process treating real coking wastewater was investigated to study the feasibility of simultaneous removal of $\mathrm{COD}$ and $\mathrm{NH}_{4}^{+}-\mathrm{N}$. Long-term operating results showed the great impact of HRT on the overall treatment efficiency. The system removed $92.3 \% \mathrm{COD}$ and $97.8 \% \mathrm{NH}_{4}^{+}-\mathrm{N}$ at an HRT of $116 \mathrm{~h}$, reaching the First Grade of the discharge standard for coking wastewater in China. In the $\mathrm{A}^{2} / \mathrm{O}^{2}$ biofilm system, the combination of anaerobic acidification, anoxic degradation, aerobic oxidation and biofilm filtration was responsible for the maximum COD removal. A two-step aerobic biofilm reactor was favorable to efficient $\mathrm{NH}_{4}^{+}-\mathrm{N}$ removal. There was an obvious correlation between pollutant removal characteristics and spatial distribution of microbial biomass at the different heights of upflow bioreactors.

\section{ACKNOWLEDGEMENT}

The authors would like to acknowledge support from the Scientific and Technological Project of Shanxi Province (No. 2006031104-02).

\section{REFERENCES}

1 Zhao Y, Pilot-scale experimental research on coking waswater treatment by the $\mathrm{A}^{2} / \mathrm{O}^{2}$ biofilm process. $\mathrm{PhD}$ thesis,Taiyuan Univiversity of Technology, China (2007).

2 Jeong YS and Chung JS, Simultaneous removal of COD, thiocyanate, cyanide and nitrogen from coal process wastewater using fluidized biofilm process. Process Biochem 41:1141 - 1147 (2006).

3 Vazquez I, Rodriguez J, Maranon E, Castrillon L and Fernandez Y, Simultaneous removal of phenol, ammonium and thiocyanate from coke wastewater by aerobic biodegradation. $J$ Hazard Mater 137:1773-1780 (2006).

4 Kim YM, Park D, Lee DS and Park JM, Instability of biological nitrogen removal in a cokes wastewater treatment facility during summer. J Hazard Mater 141:27-32 (2007). 
5 Maranon E, Vazquez I, Rodriguez J, Castrillon L, Fernandez $\mathrm{Y}$ and Lopez $\mathrm{H}$, Treatment of coke wastewater in a sequential batch reactor (SBR) at pilot plant scale. Bioresource Technol 99:4192-4198 (2008).

6 Vazquez I, Rodriguez J, Maranon E, Castrillon L and Fernandez Y, Study of the aerobic biodegradation of coke wastewater in a two and three-step activated sludge process. J Hazard Mater 137:1681-1688 (2006).

7 Qian Y, Wen Y and Zhang H, Efficacy of pre-treatment methods in the activated sludge removal of refractory compounds in coke-plant wastewater. Water Res 28:701-707 (1994).

8 Ghose MK, Complete physico-chemical treatment for coke plant effluents. Water Res 36:1127-1134 (2002).

9 Zhu XP, Ni JR and Lai P, Advanced treatment of biologically pretreated coking wastewater by electrochemical oxidation using borondoped diamond electrodes. Water Res 43:4347-4355 (2009).

10 Lai $\mathrm{P}$, Zhao HZ, Wang $\mathrm{C}$ and Ni JR, Advanced treatment of coking wastewater by coagulation and zero-valent iron processes. J Hazard Mater 147:232-239 (2007).

11 Zhu XB, Tian JP, Liu R and Chen LJ, Optimization of Fenton and electro-Fenton oxidation of biologically treated coking wastewater using response surface methodology. Sep PurifTechnol 81:444-450 (2011).

12 Suidan MT, Strubler CE, Kao SW and Pfeffer JT, Treatment of coal gasification wastewater with anaerobic filter technology. J Water Pollut Control Fed: 1263-1270 (1983).

13 Qi R, Yang K and Yu ZX, Treatment of coke plant wastewater by SND fixed biofilm hybrid system. J Environ Sci - China 19:153-159 (2007).

14 Zhu SN and Ni JR, Treatment of coking wastewater by a UBF-BAF combined process. J Chem Technol Biotechnol 83:317-324 (2008).

15 Bai YH, Sun QH, Sun RH, Wen DH and Tang XY, Bioaugmentation and adsorption treatment of coking wastewater containing pyridine and quinoline using zeolite-biological aerated filters. Environ Sci Technol 45:1940-1948 (2011).

16 Liu JX, Wang BZ, Li WG, Jin CJ, Cao XD and Wang L, Removal of nitrogen from coal gasification and coke plant wastewaters in $A / O$ submerged biofilm-activated sludge (SBF-AS) hybrid system. Water Sci Technol 34:17-24 (1996).

17 Lee MW, Park YJ, Park JM and Chun HD, Control of external carbon addition in biological nitrogen removal process for the treatment of coke-plant wastewater. Water Environ Res 73:415-425 (2001).

18 Lee MW and Park JM, Biological nitrogen removal from coke plant wastewater with external carbon addition. Water Environ Res 70:1090-1095 (1998).

19 Bridle T, Bedford W and Jank B, Biological nitrogen control of coke plant wastewaters. Water Sci Technol 13:667-680 (1981).

20 Park D, Lee DS, Kim YM and Park JM, Bioaugmentation of cyanidedegrading microorganisms in a full-scale cokes wastewater treatment facility. Bioresource Technol 99:2092-2096 (2008).

21 Chakraborty S and Veeramani H, Effect of HRT and recycle ratio on removal of cyanide, phenol, thiocyanate and ammonia in an anaerobic-anoxic-aerobic continuous system. Process Biochem 41:96-105 (2006).

22 Li YM, Gu GW, Zhaol, Yu HQ, Qiu YL and Peng YZ, Treatment of coke-plant wastewater by biofilm systems for removal of organic compounds and nitrogen. Chemosphere 52:997-1005 (2003).

23 Zhang M, Tay JH, Qian Y and Gu XS, Coke plant wastewater treatment by fixed biofilm system for COD and NH3-N removal. Water Res 32:519-527 (1998).
24 Lai P, Zhao HZ, Ye ZF and Ni JR, Assessing the effectiveness of treating coking effluents using anaerobic and aerobic biofilms. Process Biochem 43:229-237 (2008).

$25 \mathrm{Li} \mathrm{HB}$, Cao HB, Li YP, Zhang Y and Liu HR, Innovative biological process for treatment of coking wastewater. Environ Eng Sci 27:313-322 (2010).

26 Maranon E, Vazquez I, Rodriguez J, Castrillon L and Fernandez Y, Coke wastewater treatment by a three-step activated sludge system. Water Air Soil Pollut 192:155-164 (2008).

27 Papadimitriou C, Dabou X, Samaras P and Sakellaropoulos G, Coke oven wastewater treatment by two activated sludge systems. Global NEST J 8:16-22 (2006).

28 Nutt S, Melcer $\mathrm{H}$ and Pries J, Two-stage biological fluidized bed treatment of coke plant wastewater for nitrogen control. J Water Pollut Control Fed 56:851-857 (1984).

29 Sutton PM, Hurvid J and Hoeksema M, Biological fluidized-bed treatment of wastewater from byproduct coking operations: fullscale case history. Water Environ Res 71:5-9 (1999).

30 Melcer H, Nutt S, Marvan I and Sutton P, Combined treatment of coke plant wastewater and blast furnace blowdown water in a coupled biological fluidized bed system. J Water Pollut Control Fed 56:192-198 (1984).

31 Zhao WT, Huang X and Lee DJ, Enhanced treatment of coke plant wastewater using an anaerobic-anoxic-oxic membrane bioreactor system. Sep Purif Technol 66:279-286 (2009).

32 Zhao WT, Huang X, Lee DJ, Wang XH and Shen YX, Use of submerged anaerobic-anoxic-oxic membrane bioreactor to treat highly toxic coke wastewater with complete sludge retention. J Membrane Sci 330:57-64 (2009).

33 Kim YM, Park D, Lee DS and Park JM, Inhibitory effects of toxic compounds on nitrification process for cokes wastewater treatment. J Hazard Mater 152:915-921 (2008).

34 Luthy RG, Stamoudis VC, Campbell JR and Harrison W, Removal of organic contaminants from coal conversion process condensates. J Water Pollut Control Fed 55:196-207 (1983).

35 Li YX, A biological treatment process for coking wastewater. China Patent 200510012434.4 (2005).

36 Chinese EPA, Standard Monitoring and Analytical Methods for the Examination of Water and Wastewater, 4th edn. China Environmental Science Press, Beijing (2002).

37 Zhang YJ and Li CF, Biofilm determination on the carrier of the biological fluidized bed (in Chinese). Environ Pollut Control 5:33-34 (1983).

$38 \mathrm{Li} \mathrm{YM}, \mathrm{Gu}$ GW, Zhao JF and Yu HQ, Anoxic degradation of nitrogenous heterocyclic compounds by acclimated activated sludge. Process Biochem 37:81-86 (2001).

39 Rockne KJ and Strand SE, Biodegradation of bicyclic and polycyclic aromatic hydrocarbons in anaerobic enrichments. Environ Sci Technol 32:3962-3967 (1998).

40 Stephen E, Biological degradation of cyanide compounds. Curr Opin Biotechnol 15:231-236 (2004).

41 Fdz-Polanco F, Méndez E, Urueña MA, Villaverde S and García PA Spatial distribution of heterotrophs and nitrifiers in a submerged biofilter for nitrification. Water Res 34:4081-4089 (2000). 